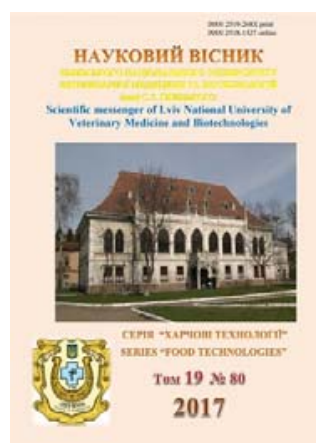

Науковий вісник Львівського національного університету ветеринарної медицини та біотехнологій імені С.З. Гжицького

Scientific Messenger of Lviv National University of Veterinary Medicine and Biotechnologies

doi:10.15421/nvlvet8017

ISSN 2519-268X print

ISSN 2518-1327 online

$\underline{\text { http://nvlvet.com.ua/ }}$

УДК 004.344.3:637.56

\title{
Сенсорний аналіз рибних січених напівфабрикатів методом профілю флейвору
}

І.Ю. Прасол, Н.В. Голембовська, Н.М. Слободянюк, О.М. Очколяс

natashagolembovska@gmail.com, slob2210@ukr.net, lenokochkolyas@gmail.com

Національний університет біоресурсів та природокористування України, вул. Героїв Оборони, 15, м. Київ, 03041, Украӥна

\begin{abstract}
У статті наведено результати сенсорного аналізу січених напівфабрикатів з нетрадиційною сировиною (насіння льону та чіа) методом профілю флейвору і встановлення їх відповідності гіпотетичному еталону. Показано доцільність його використання для очінки загального враження поєднання прісноводної риби з рослинною сировиною для розширення асортименту біологічно иінної харчової продукції.

Метод флейвору застосовують при розроблені та модифікації харчових продуктів, який дозволяс охарактеризувати комплексні відчуття в порожнині рота, зумовлені смаком, запахом і текстурою харчового продукту. Це спроба охарактеризувати «флейвор», беручи до уваги всі дескриптори, які формують загальне враження від продукту. На підставі результатів досліджень споживчих переваг, які були попередньо проведені, авторами було використано 10 дескрипторів профільного аналізу для характеристики флейвору. Сенсорний аналіз січених напівфабрикатів проведено відповідно до міжнародних стандартів ISO. Для створення профілів застосовано метод, викладений в ДСТУ ISO 6564:2005 «Дослідження сенсорне. Методологія. Методи створювання спектра флейвору».

Отримані позитивні результати органолептичних досліджень показали доиільність поєднання насіння льону та чіа 3 прісноводною рибою, про щэо свідчить високі показники таких дескрипторів, як загальне враження, гармонійний, рибний, солодкувато-солонуватий смак. За показником консистенції рибні котлети пластичні та щільні на розрізі.

Дослідним шляхом встановлено, щзо додавання нетрадииійної сировини дозволяє не лише удосконалити технологію виробництва січених напівфабрикатів, а й вирішити завдання отримання продукту підвищеної харчової иінності.

Авторами було встановлено, щь розроблена технологія рибних напівфабрикатів значно розширить асортимент продуктів функціонального призначення на основі природних компонентів, щуо дозволить в певній мірі розиирити актуальну проблему переробки сировини внутрішніх водойм України.

Ключові слова: котлети, нетрадиційна сировина, льон, чіа, напівфабрикати, органолептичне оцінювання, сенсорна характеристика, флейвор, дескриптори, профілограма.

\section{Сенсорный анализ рыбных котлет с добавлением нетрадиционного сырья методом профиля флейвора}

\author{
И.Ю. Прасол, Н.В. Голембовская, Н.М. Слободянюк, Е.Н. Очколяс
} natashagolembovska@gmail.com, slob2210@ukr.net, lenokochkolyas@gmail.com

Национальный университет биоресурсов и природопользования Украины, ул. Героев Обороны, 15, г. Киев, 03041, Украина

\footnotetext{
В статье приведены результаты сенсорного анализа рубленых полуфабрикатов с нетрадиционным сырьем (семена льна и чиа) методом профиля флейвора и установления их соответствия гипотетическому эталону. Доказана иелесообразность его использования для оченки общего впечатления сочетание пресноводной рыбы с растительным сырьем для расиирения ассортимента биологически цеенной пищевой продукции.
}

\section{Citation:}

Prasol, I., Golembovskaya, N., Slobodyanyuk, N., Ochkolyas, E. (2017). Sensory analysis of semi-finished minced fish products by the flavour profile method. Scientific Messenger LNUVMB, 19(80), 83-87. 
Метод флейвора применяют при разработке и модификации пищевых продуктов, который позволяет охарактеризовать комплексные ощущения в полости рта, обусловленные вкусом, запахом и текстурой пищевого продукта. Это попьтка охарактеризовать «флейвора», принимая во внимание все дескрипторы, которые формируют общее впечатление от продукта. На основании результатов исследований потребительских предпочтений, которые были предварительно проведены, авторами были использованы 10 дескрипторов профильного анализа для характеристики флейвора. Сенсорный анализ рубленых полуфабрикатов проведено в соответствии с международными стандартами ISO. Для создания профилей применен метод, изложенный в ДСТУ ISO 6564:2005 «Исследование сенсорное. Методология. Методы созидания спектра флейвора».

Полученные положительные результаты органолептических исследований показали целесообразность сочетания семян льна и чиа с пресноводной рыбой, о чем свидетельствует высокие показатели таких дескрипторов, как общее впечатление, гармоничный, рыбный, сладковато-солоноватый вкус. По показателю консистенции рыбные котлеты пластические и плотные на разрезе.

Опытным путем установлено, что добавление нетрадиционного сырья позволяет не только усовериенствовать технологию производства рубленых полуфабрикатов, но и решить задачу получения продукта повышенной пищевой ценности.

Авторами было установлено, что разработанная технология рыбных полуфабрикатов значительно расширит ассортимент продуктов функционального назначения на основе природных компонентов, что позволит в определенной степени решить актуальную проблему переработки пресноводной рыбы.

Ключевые слова: котлеты, нетрадиционное сырье, лен, чиа, полуфабрикаты, органолептическая оценка, сенсорная характеристика, флейвор, дескрипторы, профилограмма.

\title{
Sensory analysis of semi-finished minced fish products by the flavour profile method
}

\author{
I. Prasol, N. Golembovskaya, N. Slobodyanyuk, E. Ochkolyas \\ natashagolembovska@gmail.com, slob2210@ukr.net, lenokochkolyas@gmail.com \\ National University of Life and Environmental Sciences of Ukraine, \\ Heroyiv Oborony Str., 15, Kyiv, 03041, Ukraine
}

The article deals with the results of sensory analysis of semi-finished minced fish products with non-traditional raw materials (seeds of flax and chia) by the flavor profile method, and establishing their compliance with the hypothetical standard. It is shown the expediency of its use to assess the overall impression about the combination of freshwater fish with plant materials for the diversification of biologically valuable food products.

The flavor profile method is used for the development and modification of food products, and it allows to characterize the complex sensations in the mouth due to the taste, smell and texture of the food product. This is an attempt to characterize the "flavor», taking into account all descriptors, that form the overall impression about the product. Based on the results of previously conducted research on consumer preferences, the authors used 10 descriptor profiles for characterization of the flavor. The sensory analysis of semi-finished minced fish products was carried out in accordance with international ISO standards. For the creation of profiles they used a method, as described in DSTU ISO 6564:2005 «Sensory research, methodology, methods of creation of a spectrum of a flavor».

The obtained positive results of organoleptic studies have shown the expediency of combining the flax and chia seeds with freshwater fish, and it is proved by high indicators of such descriptors as: the overall impression, harmonious, fishy, sweet-salty taste. As for the consistency, fish cutlets are plastic and dense on the cut.

The research has established that the use of non-traditional raw materials in a production of semi-finished minced products allows not only to improve the technology of production, but also to solve the problem of obtaining the product of a high nutritional value.

The authors found that the developed technology of production of semi-finished fish products will significantly expand the range of products of functional purpose based on natural components, which will allow, to some extent, to expand the actual problem of processing raw materials from domestic reservoirs in Ukraine.

Key words: cutlet, non-traditional raw materials, flax, chia, semi-finished products, organoleptic evaluation, sensory characteristics, flavor, descriptors, profilogram.

\section{Вступ}

Прісноводна риба містить повноцінні білки, біологічно цінні жири, жиророзчинні вітаміни і фактично не містить таких нині дефіцитних, мікроелементів як йод, бром, селен, які є необхідними складовими рецептур функціональних продуктів харчування в екологічних умовах розвитку суспільства. Тому поліпшення сенсорних показників і функціональних властивостей продукції з прісноводної риби можливо за рахунок додавання рослинної сировини, яка є джерелом клітковини, мінеральних речовин та вітамінів (Golembovs'ka and Lebs'ka, 2014; Tesak et al., 2016).
Рибні напівфабрикати є одними з найбільш поширених харчових продуктів завдяки можливості їх швидкого приготування, особливо в даний час, коли прискорюється ритм життя сучасної людини. Водночас ринок України представлений, в основному, січеними напівфабрикатами із м'ясної сировини. У зв'язку 3 цим набуває актуальності наукове обгрунтування i удосконалення технології швидкозаморожених напівфабрикатів, а саме розробка технології виготовлення швидкозаморожених напівфабрикатів на основі м'яса прісноводної риби (Tesak et al., 2016). 
Метод профілю флейвору є одним із групи методів, використовуваних для опису сенсорних характеристик і вважається основоположним для багатьох інших описових методів. Цей метод рекомендують застосовувати при розроблені та модифікації харчових продуктів (Standart Nerminology Relating). Під поняттям «флейвор» розуміють комплексне відчуття в порожнині рота, зумовлене смаком, запахом і текстурою харчового продукту. Метод профілю флейвору це спроба охарактеризувати «флейвор», беручи до уваги всі дескриптори, які формують загальне враження від продукту. При використанні цього методу особливо помітними є переваги дегустаційного аналізу перед інструментальним, оскільки лише людина здатна в рамках одного виміру не тільки сприйняти множину органолептичних властивостей, а й провести їх аналіз.

По суті це спроба охарактеризувати «флейвор», беручи до уваги всі дескриптори, які формують загальне враження від продукту з точки п'яти основних критеріїв: характеру дескрипторів, їх інтенсивності, порядку прояву цих дескрипторів, після смаку та їх повноти (феномен, який виражається загальним враженням від поєднуваності складових продукту) (Stone and Sidel, 2004; Rudavs'ka and Hahaljeva, 2016).

\section{Матеріал і методи дослідження}

Мета дослідження - визначення профілю флейвору рибних напівфабрикатів (котлет) 3 додаванням нетрадиційної сировини і встановлення їх відповідності гіпотетичному еталону. Для досягнення поставленої мети були виконані такі завдання: розробка нових рецептур рибних напівфабрикатів; розробка дескрипторів, які входять до комплексного профілю флейфору еталону; проведення сенсорного аналізу рибних напівфабрикатів за методом флейвору.

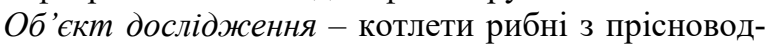
ної риби з додаванням насіння чіа та льону. Предмет дослідження - органолептичні показники та сенсорний аналіз. Порівняння проведено як з еталоном (теоретично розробленою моделлю), так і між досліджуваними зразками.

Зразки напівфабрикатів підібрали з урахуванням вмісту в них основних компонентів: 1 зразок - 3 додаванням насіння льону; 2 зразок - 3 додаванням насіння чіа, контрольний зразок - без добавок, лише на основі м'яса товстолобика.

Процес виробництва швидкозаморожених напівфабрикатів (котлет) складається 3 таких операцій: приймання сировини, сортування, миття, розбирання на філе, подрібнення, приготування фаршу, формування, панірування, заморожування, фасування в споживчу тару, упакування в транспортну тару та зберігання.

Сенсорний аналіз рибних котлет проведено відповідно до міжнародних стандартів ISO. Для створення профілів застосовано метод, викладений в ДСТУ ISO 6564:2005 «Дослідження сенсорне. Методологія. Методи створювання спектра флейвору» (Doslidzhennja sensorne, 2006).
Дегустацію проведено експертною комісією у складі 8 осіб. При цьому оцінювалися дескриптори, які є значущими для споживачів і входили в комплексний профіль флейвору гіпотетичного еталону.

Респондентам для оцінки рибних котлет за наведеною шкалою запропоновано 10 дескрипторів, які було розставлено в порядку спадання значущості.

За результатами дегустації, після математичної обробки, складалися профілі флейвору розроблених зразків котлет рибних з додаванням насіння чіа, льону та контрольного зразка - без додавання рослинної сировини.

Дегустаційну оцінку зразків рибних котлет проведено за 5-бальною шкалою бажаності та інтенсивності відчуття ароматичних і смакових властивостей продукту: 0 балів - ознака відсутня; 1 бал - ледь відчутна; 2 бали - слабка інтенсивність; 3 бали - середня інтенсивність; 4 бали - сильна інтенсивність; 5 балів дуже сильна інтенсивність (Ochkoljas and Lebs'ka, 2016).

Смаковитість - це відчуття, яке залишається в ротовій порожнині й затримується носом, тобто $є$ комплексною характеристикою.

Із вибраних дескрипторів один відводився для оцінки загального враження, (враховує адекватність характеристик, що сприймають їхню інтенсивність, фоновий флейвор, який ідентифікується), 6 - смаку та аромату і 3 - для характеристики відчуття дотику в ротовій порожнині, що оцінюється показником консистенції рибних котлет.

Серед дескрипторів смаку виділено гармонійний, що $є$ тотожним поняттям збалансованості продукту, тобто поєднання компонентів в оптимальній пропорціï. Дескриптори гармонійний, властивий, рибний, слабо виражений, солодкий і солонуватий присмак характеризують повноту смаку рибних котлет. Дегустатори спочатку розкривали запах (аромат), після чого визначали інтенсивність прояву кожного компонента на смак із подальшим окресленням залишкового присмаку (стійкості).

\section{Результати та їх обговорення}

На підставі результатів досліджень споживчих переваг, які були попередньо проведені нами (Tesak et al., 2016; Tesak et al., 2016), визначено набір за 10 дескрипторами для характеристики флейвору (табл. 1).

У результаті проведених експериментальних досліджень встановлено, що гармонійний та властивий смак $з$ інтенсивністю в 5 балів притаманний всім розробленим дослідним зразкам порівняно з контролем, який мав недостатньо високу інтенсивність та наявний сильний рибний післясмак.

За ароматом більшість досліджених зразків котлет мали досить високу інтенсивність позитивних характеристик. Вони отримали найвищі оцінки, а за складовою «слабовиражений» перевищують показник еталону. Негативних складових аромату, сторонніх та різких запахів не виявлено. 
Сенсорна оцінка рибних котлет методом профілю флейвору

\begin{tabular}{|l|c|c|c|c|}
\hline \multirow{2}{*}{\multicolumn{2}{|c|}{ Дескриптори }} & \multicolumn{4}{|c|}{ Інтенсивність характеристик, бал } \\
\cline { 2 - 5 } & \multicolumn{3}{|c|}{ рибні котлети } \\
\cline { 2 - 5 } & еталон & контроль & із насінням льону & із насінням чіа \\
\hline $\begin{array}{l}\text { Характеристика аромату та смаку: } \\
\text { гармонійний }\end{array}$ & 5,0 & $4,0 \pm 0,10$ & $5,0 \pm 0,10$ & $5,0 \pm 0,20$ \\
\hline властивий & 4,5 & $3,0 \pm 0,01$ & $4,0 \pm 0,01$ & $4,0 \pm 0,02$ \\
\hline рибний & 4,5 & $4,5 \pm 0,10$ & $4,5 \pm 0,10$ & $4,5 \pm 0,10$ \\
\hline слабо виражений & 3,5 & $1,0 \pm 0,02$ & $3,0 \pm 0,01$ & $3,5 \pm 0,01$ \\
\hline солодкий & 3,0 & $3,0 \pm 0,01$ & $2,5 \pm 0,01$ & $3,0 \pm 0,01$ \\
\hline солонуватий & 3,0 & $3,0 \pm 0,01$ & $2,5 \pm 0,01$ & $2,5 \pm 0,10$ \\
\hline $\begin{array}{l}\text { Характеристика консистенцї: } \\
\text { соковита }\end{array}$ & 3,0 & $3,0 \pm 0,10$ & $2,0 \pm 0,20$ & $1,5 \pm 0,10$ \\
\hline пластична & 3,5 & $3,0 \pm 0,10$ & $3,5 \pm 0,20$ & $3,5 \pm 0,10$ \\
\hline щільна & 1,0 & $2,0 \pm 0,02$ & $2,5 \pm 0,02$ & $3,0 \pm 0,02$ \\
\hline Загальне враження & 5,0 & $4,8 \pm 0,10$ & $5,0 \pm 0,20$ & $5,0 \pm 0,10$ \\
\hline Сума балів & 36,0 & $31,3 \pm 1,00$ & $34,5 \pm 1,00$ & $35,5 \pm 0,40$ \\
\hline
\end{tabular}

Для наочного сприйняття результатів побудовано розгорнуті профілографи флейвору розроблених зразків рибних котлет (рис. 1-3). Саме профільний аналіз дає можливість виявити, за рахунок якої інтенсивності позитивних і наявності негативних характеристик смаку й аромату один досліджуваний зразок (контроль) відрізняється від іншого (дослідні). Отже, за допомогою профільного аналізу отримано більш об’єктивну оцінку органолептичних показників рибних котлет.

Рибні котлети (контроль) характеризувались світло-сірим кольором, солодко-солонуватим смаком, пластичною, щільною за всією масою консистенцією, що свідчить про необхідність коригування їхніх рецептур для максимального наближення до еталону (рис. 1).

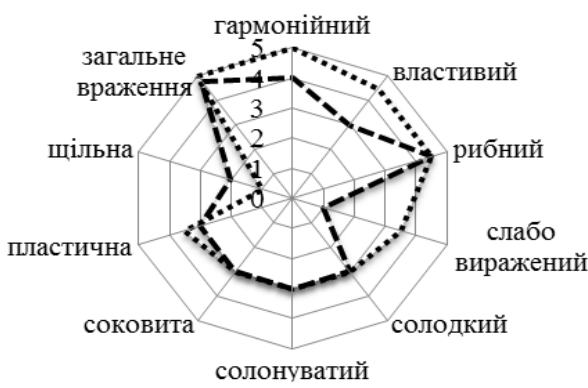

:Еталон

$\mathbf{u}$ Контроль

Рис. 1. Профілограма флейвору рибних котлет (контроль)

В результаті органолептичних досліджень було встановлено доцільність поєднання насіння льону 3 прісноводною рибою, про що свідчить приємний, властивий, без стороннього присмаку, маловиражений рибний смак та щільна, ніжна консистенція.

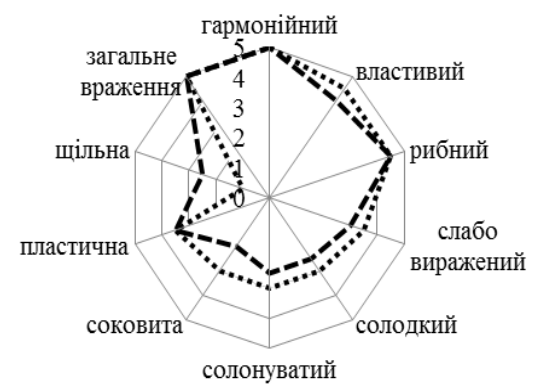

:Еталон

ᄂРибні котлети із насінням льону

\section{Рис. 2. Профілограма флейвору рибних котлет 3 додаванням насіння льону}

Котлети 3 додаванням насіння чіа характеризуються високими показниками таких дескрипторів, як загальне враження, гармонійний, рибний, солодкувато-солонуватий смак. За показником консистенції рибні котлети пластичні та щільні на розрізі.

Порівнюючи розраховану загальну оцінку в балах, бачимо, що найбільш наближеними до еталону є зразок рибних котлет 3 додаванням насіння чіа -3 оцінкою 35,5 (рис. 3).

Різницею в 4,7 та 1,5 бала від еталону мають зразки рибних котлет (контроль) та рибні котлети з додаванням насіння льону, що свідчить про необхідність коригування їхніх рецептур для максимального наближення до еталону.

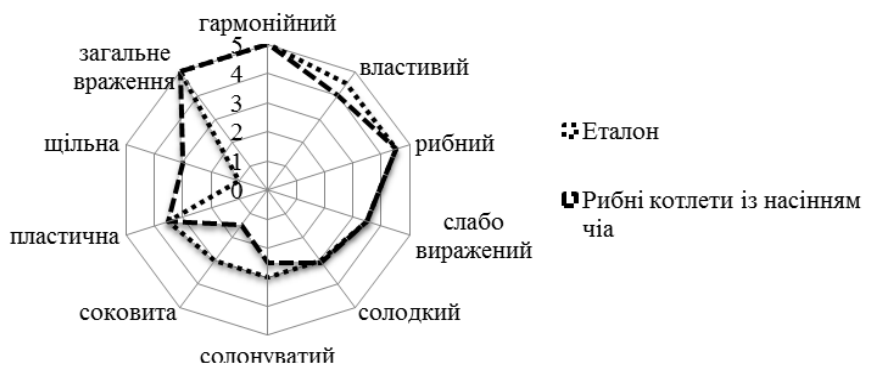

Рис. 3. Профілограма флейвору рибних котлет з додаванням насіння чіа 
Загальний порівняльний аналіз дає змогу стверджувати, що всі зразки рибних котлет мають позитивне загальне враження, гармонійний і рибний смак.

\section{Висновки}

Розроблена технологія рибних напівфабрикатів значно розширить асортимент продуктів функціонального призначення на основі природних компонентів, що дозволить в певній мірі розширити актуальну проблему переробки прісноводної риби.

Перспективи подальших досліджень. Отримані позитивні дослідження свідчать про продовження вивчення даної технології і потребують подальших розробок.

\section{Бібліографічні посилання}

Golembovs'ka, N.V., Lebs'ka, T.K. (2014). Harakterystyka harchovoi' cinnosti preserviv $\mathrm{Z}$ prisnovodnoi' ryby $\mathrm{z}$ dodavannjam prjanoaromatychnyh koreneplodiv. «Naukovi zdobutky molodi u vyrishenni aktual'nyh problem vyrobnyctva ta pererobky syrovyny, standartyzacii' i bezpeky prodovol'stva»: mizhnar. naukovo-prakt. konf. molodyh vchenyh, aspirantiv i studentiv: tezy dop. K.: NUBiP Ukrai'ny, 25-26 (in Ukrainian).

Tesak, Ju.I., Golembovs'ka, N.V., Slobodjanjuk, N.M. (2016). Tehnologija shvydkozamorozhenyh napivfabrykativ. Nauchnye trudy SWorld. 45(3), 1114 (in Ukrainian).
Standart Nerminology Relating to Sensory Evaluations of Materials and Products. The American Society for Testing and Materials. Flavor. - Way of access: http://www.sensorysociety.org/knowledge/sspwiki/Pa ges/Flavor\%20Flavor.aspx\#ref1

Stone, H., Sidel, J.L. (2004). Sensory evaluation practices. Food science and technology. International series. Way of access: http:/www.geocities.ws/saqibuos/files/ Sensory\%20Evaluation \%20Practices.pdf.

Rudavs'ka, G., Hahaljeva, I. (2016). Sensornyj analiz vidnovlenyh napoi'v iz cykoriju metodom profilju flejvoru. Mizhnar. nauk.-prakt. zhurn. Tovary i rynky. 1, 131-136 (in Ukrainian).

Doslidzhennja sensorne (2006). Metodologija. Metody stvorennja spektra flejvoru (ISO 6564:1985, IDT: DSTU ISO 6564:2005. [Chynnyj vid 2005 - 05 - 25]. K.: Derzhspozhyvstandart Ukrai'ny, 9 (in Ukrainian).

Ochkoljas, O.M., Lebs'ka, T.K. (2016). Sensornyj analiz vershkovogo masla iz mors'kymy vodorostjamy metodom profilju flejvora. Tovary i rynky. 2, 109-117 (in Ukrainian).

Tesak, Ju.I., Golembovs'ka, N.V., Ochkoljas, O.M. (2016). Tehnologija shvydkozamorozhenyh napivfabrykativ zbagachenyh mors'kymy vodorostjamy. Nauchnye trudy SWorld. 3(44), 89 - 93 (in Ukrainian). 